\title{
Parameters Optimization of 'Anjul' Seed Metering Mechanism for Okra Seeds
}

\author{
Vinod Kumar*, Vijaya Rani, Mukesh Jain, Anil Kumar, Sushil Kumar and Naresh \\ Department of Farm Machinery and Power Engineering, CCS Haryana Agricultural \\ University, Hisar-125004, Haryana, India \\ *Corresponding author
}

\section{A B S T R A C T}

\section{Keywords}

Anjul, Seed metering, Planter, Cell fill percentage, Seed rate

Article Info

Accepted:

12 February 2018 Available Online: 10 March 2018

\begin{abstract}
Seed metering mechanism is an integral part of any planter. A seed metering mechanism was developed aimed to meter spherical seeds of okra. It consisted of cells termed 'Anjul' (a double handful) on its periphery, seed box, feeding chute, cleaning brush and seed capturing conical funnel. It was evaluated for three cell sizes-7 mm, $8 \mathrm{~mm}$ and $9 \mathrm{~mm}$ at three peripheral speeds of seed metering roller- $1.2 \mathrm{kmh}^{-1}, 1.4 \mathrm{kmh}^{-1}$ and $1.6 \mathrm{kmh}^{-1}$. Influence of cell size and peripheral speed of seed metering roller on seed rate and cell fill percentage was studied. The seed rate of okra seed varied between $12.89 \mathrm{kgha}^{-1}$ to 22.99 $\mathrm{kgha}^{-1}$ for different combinations of the cell sizes and the peripheral speeds. The cell fill percentage of the three cell sizes for okra seed ranged from 42.80 to 54.72 for different combination of the cell sizes and the peripheral speeds of the seed metering roller. Optimum values for planting okra seeds were found to be $7 \mathrm{~mm}$ cell size at peripheral speed of seed metering roller of $1.4 \mathrm{kmh}^{-1}$ for a desired seed rate of $13.75 \mathrm{kgha}^{-1}$.
\end{abstract}

\section{Introduction}

Seed metering mechanism is the core component of any planting machine. The metering mechanism affects the design parameters and performance of the planter. It is one of the most difficult part to optimize because for this, researcher has to deal with crop seeds which are highly variable in terms of their shapes and sizes. In traditional farming, the farmer places the seeds on seed bed manually. The non-uniform plant population which is a common characteristic of manual dibbling of seeds adversely affects the crop output (Singh et al., 2007). It is essential to keep seed distribution uniform in terms of seed to seed distance as well as row to row distance. This result into increases in crop yield, reliability of cropping and crop returns (Murray et al., 2006).

The assessment of parameters like quality of feed index, desired seed rate, cell fill percentage, etc. is crucial in analyzing the performance of any metering mechanism. These parameters depend upon cell sizes and peripheral speeds of metering mechanism for the seeds of a particular crop. The peripheral speed of seed metering discs of the planting equipment and optimum area of cells on the metering plate had good correlation with size of seed (Anantachar et al., 2010). Lower miss 
indices occurs at higher pressures and lower speeds, and lower multiple indices at lower pressure and higher speeds in a pneumatic metering device (Singh et al., 2005). The number of seeds metered, or seed rate in other words, also vary at different forward speed of the planter which is directly related to peripheral speed of seed metering discs (Reddy et al., 2012). The cell fill percentage which accounts for the volume of cell occupied by the seed(s) is also dependent on the cell area and speed of rotation of metering disc.

A number of methods have been used to optimize the variables of seed metering mechanism for the crop seeds. In the present study, the study of the influence of these variables on performance of 'Anjul' seed metering mechanism for okra seeds was conducted and a optimization of the machine variables is formulated.

\section{Materials and Methods}

\section{The 'Anjul' seed metering mechanism}

The 'Anjul' seed metering mechanism consisted of two semi-circular split seed rollers mounted on a circular flange and a seed box with feeding chute (Fig. 1). The seed rollers have cells termed as 'Anjul' (a Hindi word, meaning- a double handful, because of its shape resemblance) on its periphery. A cleaning brush was attached to feeding chute at top of the seed roller to wipe any extra seed in cells.

A flow control plate was mounted on seed box to avoid the expected overflow of seed in feeding chute. The seed box was made from mild steel plate having thickness $1.5 \mathrm{~mm}$. The feeding chute was attached to the bottom of the seed box to feed seed to the seed roller. The slop of bottom surface of the feeding chute was $35^{\circ}$ to the horizontal.
The shape of the cell was a scalene ellipsoid having cut by a cylindrical surface of radius 6 $\mathrm{cm}$ resulting into a ellipse mouth with two axes viz. major and minor (Fig. 2). The cell was a hemisphere at bottom to hold the seed and a trowel at top to guide seed to the hemispherical part. The cell size is designated by minor axis of the elliptical mouth of the cell (Fig. 2) measured along axis of rotation of seed roller at its periphery as seed accommodated by the cell depends majorly on it.

\section{Test preparation}

The okra seeds were cleaned from foreign materials, damaged seeds and impurities by manual picking and then passing through a metal screen having square pores of size $10 \mathrm{~mm}$. It was taken in the seed box. The seed metering mechanism was provided power from the ground wheel of the planter. The metering mechanism was subjected to three different peripheral speeds of seed metering roller and three different cell sizes. Different peripheral speeds of seed metering roller were achieved by changing teeth ratio of the ground wheel sprocket and seed metering roller sprocket. There were three seed metering roller sprockets which had 40, 44 and 54 numbers of teeth. The ground wheel sprocket had 20 teeth. Influences of machine variables on seed rate and cell fill percentage were studied.

\section{Optimization parameters of the seed metering mechanism}

\section{Seed rate}

Okra seeds are filled in the seed box. The planter is jacked up and 20 revolutions are given to the ground wheel at uniform rate by a direct current electric drive. The seed discharged from each seed tube is collected and weighed. Three replications were taken 
for the study. Seed rate $\left(\mathrm{kgha}^{-1}\right)$ is determined by using following equation:

$\mathrm{Q}=\frac{\mathrm{q} \times 10000}{\pi \times \mathrm{D} \times \mathrm{n} \times W}$

Where,

$\mathrm{Q}=$ Seed rate, $\mathrm{kgha}^{-1}$

$\mathrm{q}=$ Seed delivery in given number of revolutions (n) of ground wheel, $\mathrm{kg}$

$\mathrm{D}=$ Effective diameter of ground wheel, $\mathrm{m}$

$n=$ Number of revolutions of ground wheel, and

$\mathrm{W}=$ Nominal working width of the planter, $\mathrm{m}$

\section{Cell fill percentage}

The cell fill percentage affects the seed rate. Seeds collected by cells of seed metering device is measured in terms of volumetric cell fill percentages, and expressed as under:

$V_{\mathrm{cf}}=\frac{\mathrm{W} \times \mathrm{rx} 100}{\gamma \times \mathrm{nxN}}$

Where,

$\mathrm{V}_{\mathrm{cf}}=$ Volumetric cell fill percentage

$\mathrm{W}=$ Weight of seed collected in 20 revolution, $\mathrm{g}$

$r=$ Speed ratio of driven and driving sprockets

$\gamma=$ Bulk density of metered seed, $\mathrm{gcm}^{-3}$

$\mathrm{n}=$ Number of cells on seed metering roller

$\mathrm{V}=$ Volumetric capacity of each cell, $\mathrm{cm}^{3}$

$\mathrm{N}=$ Number of revolutions of ground wheel

\section{Results and Discussion}

Experiments were conducted in the laboratory to study the various machine variables and their interaction for selection of optimum machine parameters.

\section{Seed rate}

The seed rate of okra seed varied between $12.89 \mathrm{kgha}^{-1}$ to $22.99 \mathrm{kgha}^{-1}$ for three levels of each- cell size and peripheral speed of seed metering roller. The mean seed rates of three replications are given in Table 1. The statistical analysis of data on the influence of study variables on seed rate is given in Table 2.

\section{Influence of cell size on seed rate}

The seed rate is varied linearly with change in cell size (Fig. 3). The seed rate is influenced by peripheral speed of roller to lesser extent in comparison to cell size. The effect of cell size coupled with peripheral speed of seed metering roller on seed rate is not significant. For the $7 \mathrm{~mm}$ cell, the seed rate varied between $12.89 \mathrm{kgha}^{-1}$ and $14.52 \mathrm{kgha}^{-1}$ at different levels of peripheral speed of seed roller.

The seed rate ranged from $16.10 \mathrm{kgha}^{-1}$ to $18.10 \mathrm{kgha}^{-1}$ for $8 \mathrm{~mm}$ cell at different levels of peripheral speed of seed roller. In case of 9 $\mathrm{mm}$ cell, it varied between $20.89 \mathrm{kgha}^{-1}$ and $22.35 \mathrm{kgha}^{-1}$. Anantachar et al., (2010) also reported that increase in cell area on the seed metering plate resulted into increase in the seed rate. The $7 \mathrm{~mm}$ cell mostly accommodates one seed per cell whereas 8 $\mathrm{mm}$ and $9 \mathrm{~mm}$ cell holds mostly 1-2 and 2-3 seeds, respectively. Hongxin et al., (2015) reported similar trends onre-seeding rate (reseeding means more than one seed in a hole) of multi-size seed metering device for vertical plate precision planter. 
Table.1 Mean of seed rate $\left(\mathrm{kgha}^{-1}\right)$ at different cell sizes and different peripheral speeds of seed roller

\begin{tabular}{|c|c|c|c|c|}
\hline & \multicolumn{3}{|c|}{ Peripheral speed of seed metering roller } \\
\hline & & $1.20 \mathrm{kmh}^{-1}$ & $1.40 \mathrm{kmh}^{-1}$ & $1.60 \mathrm{kmh}^{-1}$ \\
\hline$\overline{8}$ & $7 \mathrm{~mm}$ & 13.06 & 13.55 & 14.40 \\
\hline$=$ & $8 \mathrm{~mm}$ & 16.42 & 17.08 & 17.91 \\
\hline లँ & $9 \mathrm{~mm}$ & 21.05 & 21.66 & 22.14 \\
\hline
\end{tabular}

Table.2 Analysis of variance (ANOVA) for seed rate

\begin{tabular}{|l|c|c|c|c|}
\hline Source of variation & $\begin{array}{c}\text { Sum of } \\
\text { squares }(\mathbf{S S})\end{array}$ & $\begin{array}{c}\text { Degree of } \\
\text { freedom }\end{array}$ & $\begin{array}{c}\text { Mean } \\
\text { Square value }\end{array}$ & \multirow{2}{*}{ F-Statistic } \\
\hline Cell size & 285.65 & 2 & 142.82 & $1422.77^{*}$ \\
\hline Peripheral speed of seed roller & 7.72 & 2 & 3.86 & $38.46^{*}$ \\
\hline Cell size x Peripheral speed of & 0.17 & 4 & 0.04 & 0.44 \\
\hline seed roller & & & & \\
\hline Error & 1.80 & 18 & 0.1 & \\
\hline Total & 295.35 & 26 & & \\
\hline
\end{tabular}

* Significant at 5 per cent level

Table.3 Mean of cell fill percentage at different cell sizes and different peripheral speeds of the seed roller

\begin{tabular}{|c|c|c|c|c|}
\hline & \multicolumn{3}{|c|}{ Peripheral speed of seed metering roller } \\
\hline & & $1.20 \mathrm{kmh}^{-1}$ & $1.40 \mathrm{kmh}^{-1}$ & $1.60 \mathrm{kmh}^{-1}$ \\
\hline \multirow{3}{*}{$\begin{array}{l}\frac{8}{6} \\
\overline{0} \\
\delta\end{array}$} & $7 \mathrm{~mm}$ & 43.41 & 45.02 & 47.84 \\
\hline & $8 \mathrm{~mm}$ & 45.19 & 46.96 & 49.24 \\
\hline & $9 \mathrm{~mm}$ & 51.50 & 52.98 & 54.21 \\
\hline
\end{tabular}

\section{Table.4 ANOVA for cell fill percentage}

\begin{tabular}{|l|c|c|c|c|}
\hline Source of variation & $\begin{array}{c}\text { Sum of } \\
\text { squares (SS) }\end{array}$ & $\begin{array}{c}\text { Degree of } \\
\text { freedom }\end{array}$ & $\begin{array}{c}\text { Mean } \\
\text { Square value }\end{array}$ & F-Statistic \\
\hline Cell size & 276.31 & 2 & 138.15 & $169.79 *$ \\
\hline $\begin{array}{l}\text { Peripheral speed of seed } \\
\text { roller }\end{array}$ & 62.98 & 2 & 31.49 & $38.7 *$ \\
\hline $\begin{array}{l}\text { Cell size xPeripheral speed } \\
\text { of seed roller }\end{array}$ & 2.96 & 4 & 0.74 & 0.91 \\
\hline Error & 14.64 & 18 & 0.81 & \\
\hline Total & 356.91 & 26 & & \\
\hline
\end{tabular}

* Significant at 5 per cent level 
Fig.1 Seed box with seed roller and cleaning brush
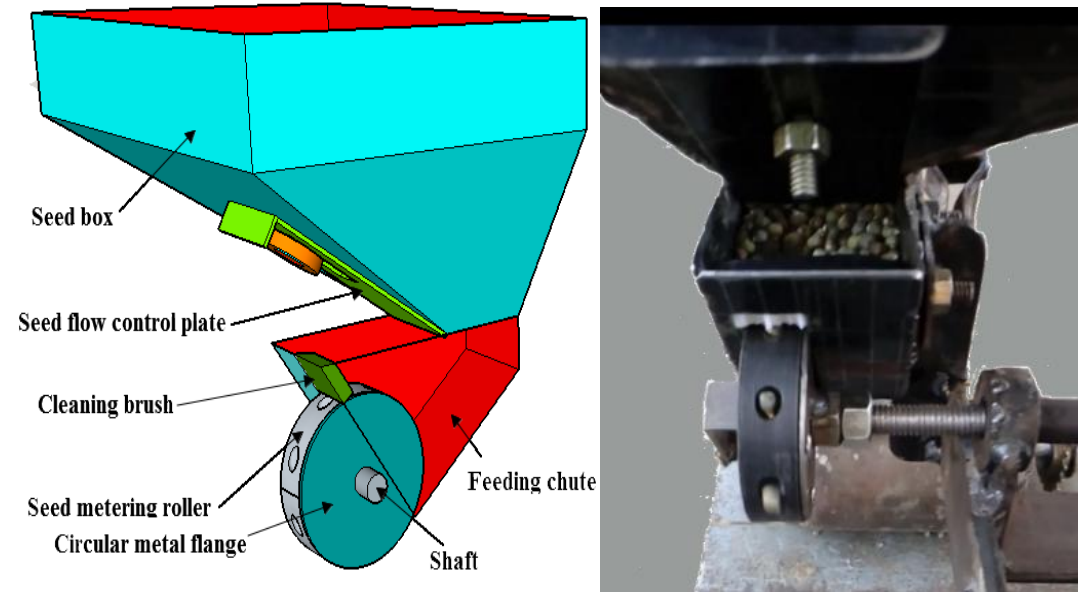

Fig.2 Dimension of the 'Anjul' cell (Left: side view, Right: top view)

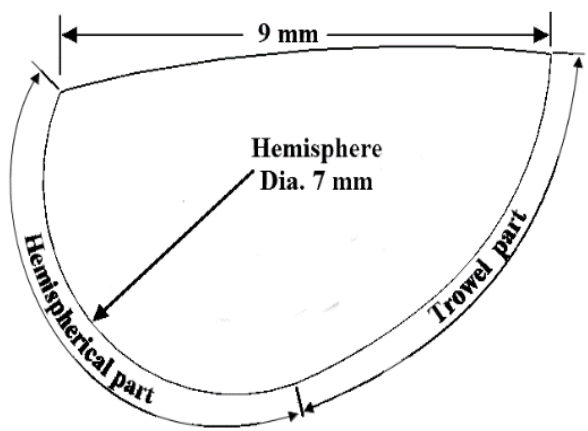

Fig.3 Effect of cell size and peripheral speed of seed roller on seed rate

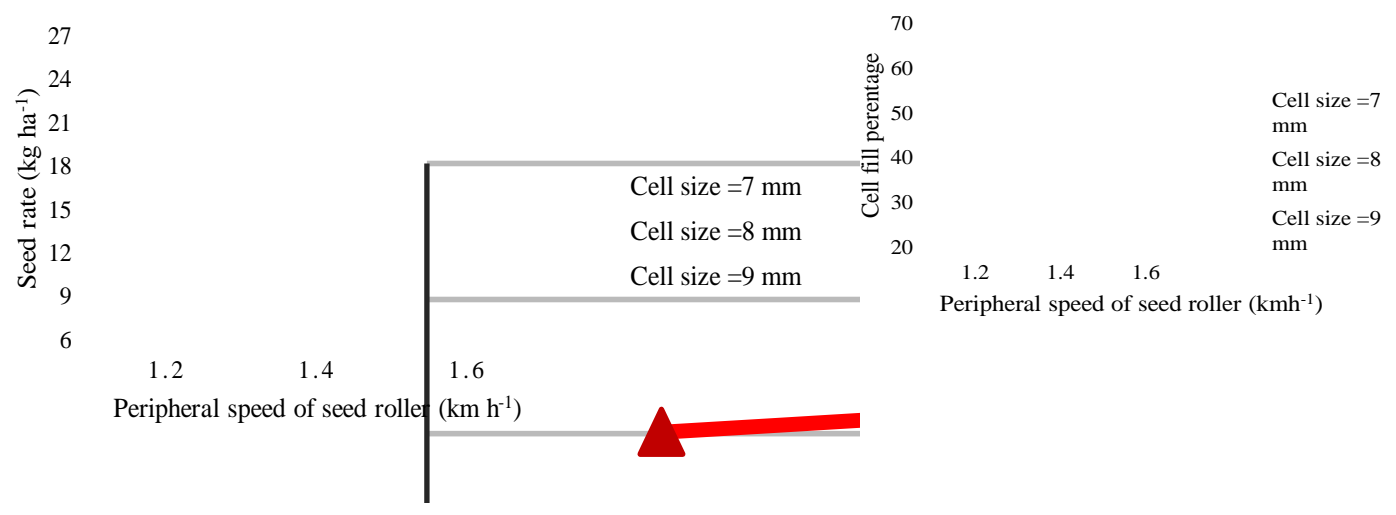

Fig.4 Effect of cell size and peripheral speed of roller on cell fill percentage

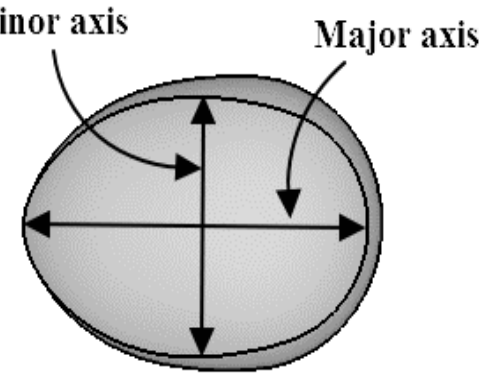




\section{Influence of peripheral speed of roller on seed rate}

Peripheral speed of seed roller affects the seed rate of the machine significantly as shown by ANOVA in Table 2. It is less pronounced as compared to effect of cell size on seed rate. As peripheral speed of seed metering roller increases, seed rate increases (Fig. 3). For 1.2 $\mathrm{kmh}^{-1}$ peripheral speed of seed roller, the seed rate varied between $13.09 \mathrm{kgha}^{-1}$ and 21.30 $\mathrm{kgha}^{-1}$ at different levels of cell size. The seed rate ranged from $13.12 \mathrm{kgha}^{-1}$ to $21.95 \mathrm{kgha}^{-1}$ for $1.4 \mathrm{kmh}^{-1}$ peripheral speed of seed roller at different levels of cell size. In case of 1.6 $\mathrm{kmh}^{-1}$ peripheral speed of seed roller, at different levels of cell size, the seed rate varied between $14.3 \mathrm{kgha}^{-1}$ and $22.1 \mathrm{kgha}^{-1}$.

Higher peripheral speed of seed roller leads to decreased efficiency of cleaning brush which creates the measured increase in the seed rate. The nylon bristles of cleaning brush, at high speed of seed roller, does not re-position itself to its normal position due to availability of short time span to do so. This results into poor cleaning efficiency of the brush at higher speed of seed roller. Anantachar et al., (2010) reported the peripheral speed of the metering plate has the highest influence on the performance parameters of the metering device.

\section{Cell fill percentage}

The cell fill percentage of different cell sizes for okra seed ranged from 42.80 to 54.72 at different peripheral speed of seed roller for different cell sizes. The mean of the cell fill percentage of three replications is given in Table 3. The statistical analysis of data on the influence of study variables on cell fill percentage is given in Table 4 .

\section{Influence of cell size on cell fill percentage}

The cell fill percentage is significantly affected by cell size. It ranged from 42.82 to $48.21,44.29$ to 49.75 and 51.09 to 54.72 for 7 $\mathrm{mm}, 8 \mathrm{~mm}$ and $9 \mathrm{~mm}$ cell size, respectively, at three different levels of peripheral speed of seed metering roller. The cell fill percentage increases as cell size increases (Fig. 4).

This result is attributed to the increase in number of seeds accommodated per cell when cell sizes increases. In other words, increase in cell volume with increase in cell size results into increase in cell fill percentage. But cell fill percentage does not differ greatly as cell size changes. This effect is attributed to the fact that increase in seed accommodated per cell when cell size increases, is also accompanied by corresponding increase in cell volume. Hongxin et al., (2015) reported increase in cavity rate (cavity means no seed in a hole) with increase in cell size.

\section{Influence of peripheral speed of seed roller on cell fill percentage}

The peripheral speed of seed roller significantly affects the cell fill percentage. The cell fill percentage increases slightly as peripheral speed of seed roller increases (Fig. 4). It varied between 42.82 to $52.12,43.57$ to 53.69 and 47.47 to 54.72 for $1.20 \mathrm{kmh}^{-1}, 1.40$ $\mathrm{kmh}^{-1}$ and $1.60 \mathrm{kmh}^{-1}$ peripheral speed of seed roller, respectively, for different cell sizes. This can also attributed to the fact that there is small change in weight of seeds collected in twenty revolutions at different peripheral speed of seed roller for cell of same size. Hongxin et al., (2015) reported similar trends for cavity rate of multi-size seed metering device for vertical plate precision planter. Anantachar et al., (2010) also reported similar trends. 


\section{Optimization of variables of seed metering mechanism for okra seeds}

From the above results, the desired seed rate of okra seed [13.75 $\mathrm{kgha}^{-1}$, average of the recommended seed rate of $12.5 \mathrm{kgha}^{-1}-15$ $\mathrm{kgha}^{-1}$ (Anonymous, 2013)was obtained for 7 $\mathrm{mm}$ cell at $1.40 \mathrm{kmh}^{-1}$ peripheral speed of seed metering roller. Also, $7 \mathrm{~mm}$ cell accommodated single seed in the cell most of the time whereas $8 \mathrm{~mm}$ and $9 \mathrm{~mm}$ cell holds mostly 1-2 and 2-3 seeds. Therefore, optimum values of cell size and peripheral speed of seed roller was found to be of $7 \mathrm{~mm}$ and 1.4 $\mathrm{kmh}^{-1}$, respectively.

The developed metering device can be successfully used for planting okra seeds for desired seed rate at different peripheral speeds of seed metering roller. The statistical analysis revealed that seed rate is significantly dependent upon the cell size and peripheral speed of seed metering roller. The cell fill percentage although vary with these two variable significantly, but the effect is not as pronounced as that for seed rate. The cell size of $7 \mathrm{~mm}$ and peripheral speed of $1.4 \mathrm{kmh}^{-}$ ${ }^{1}$ was found suitable for desired seed rate of $13.75 \mathrm{kgha}^{-1}$ for okra seeds.

\section{References}

Anantachar, M., Kumar, P.G.V., and Guruswamy, T. 2010. Neural network prediction of performance parameters of an inclined plate seed metering device and its reverse mapping for the determination of optimum design and operational parameters. Computers and Electronics in Agriculture (COMPUT ELECTRON AGR). 72(2): 87-98.

Anonymous, 2013. Phal Phul Sabji Uttapadan Avam Parirakshan (Package Practice). Directorate of Extension Education, Chaudhary Charan Singh Haryana Agricultural University, Hisar.

Hongxin, L., Lifeng, G., Lulu, F., and Shifa, T. 2015. Study on multi-size seedmetering device for vertical plate soybean precision planter. Int J Agric \& Biol Eng. 8(1): 1-8.

Murray, J.R., Tullberg, J.N., and Basnet, B.B. 2006. Planters and their components: types, attributes, functional requirements, classification and description. ACIAR Monograph No. 121.

Reddy, B.S., and Adake, R.V. 2012. Performance of Seed Planter Metering Mechanisms under Simulated Conditions. Indian J. Dryland Agric. Res. \& Dev. 27(2):36-42.

Singh, H., Kushwaha, H.L., and Mishra, D.2007. Development of seed drill for sowing on furrow slants to increase the productivity and sustainability of arid crops. Biosystems Engineering. 98: 176-184.

Singh, R.C., Singh, G., and Saraswat, D.C. 2005. Optimization of design and operational parameters of a pneumatic seed metering device for planting cotton seeds. Biosyst. Eng. 92 (4): 429-438.

\section{How to cite this article:}

Vinod Kumar, Vijaya Rani, Mukesh Jain, Anil Kumar, Sushil Kumar and Naresh. 2018. Parameters Optimization of 'Anjul' Seed Metering Mechanism for Okra Seeds. Int.J.Curr.Microbiol.App.Sci. 7(03): 1544-1550. doi: https://doi.org/10.20546/ijcmas.2018.703.184 